\title{
Прогресс в мощных фемтосекундных волоконных и гибридных системах
}

\author{
Андрей Стародумов \\ Когерент \\ *E-mail: andrei.starodoumov@coherent.com
}

\begin{abstract}
DOI:10.31868/RFL2018.235
Фемтосекундные лазерные системы находят новые применения в обработке материалов, научных, медицинских и биологических приложениях. Спектр таких применений включает резку напряженного стекла, выращивание искуственных органов, доставку лекарстственных препаратов к определенным органам в человеческом теле, и оптогенетику, где свет используется для контроля активности клеток мозга животных. Свехкороткие импульсы позволяют записывать структуры в прозрачных материалах с высоким пространственным разрешением, что ведет к созданию новых оптических компонент. Наряду с минимизацией тепловых изменений в структуре материала использование свехкоротких импульсов позволяет контролировать глубину обработки материала, качество боковых поверхностей и уменьшает пост-обработку материала.

Основным источником сверкоротких импульсов долгие годы являлись лазеры на кристаллах Ti:Sapphire работающие в диапазоне 700-900 нм и накачиваемые 2-ой гармоникой от лазеров на кристаллах легированных ионами неодима. Появление волоконных лазеров и твердотельных усилителей на ионах иттербия привело к снижение стоимости систем генерирующих сверкороткие импульсы. Повышение надежности диодных лазеров на 920-980 нм привели к постепенному переходу от фемтосекундных систем на кристаллах Ti:Sapphire к системам на ионах иттербия. Это позволило поднять средние мощности лазерных систем с короткими импульсами 1 пс до киловаттного уровня с энергиями превышающими 10 мДж. Однако ширина полосы усиления материлов на ионах иттербия значительно уступает ширине полосы ионов титана, что привело к необходимости поисков новых методов сжатия импульсов до 5- 100 фс необходимых для новых научных и промышленных применений. Полые волоконные свтоводы, капилляры наполненные инертным газом, многопроходные системы с фазовой самомодуляцией в тонких пластинах и в газовой среде позволили значительно сократить длительности мощных систем работающих в диапазоне 1020-1060 нм. В докладе обсуждаются основные принципы построения систем генерирующих сверхкороткие импульсы и базирующихся на волоконных или волоконно-твердотельных гибридных схемах с усилителями на тонких дисках и слэбах и оцениваются оптимальные диапазоны параметров для различных конфигураций. Обсуждаются новые методы сжатия импульсов, а также перспективные применения и характеристики излучения необходимые для этих применений.
\end{abstract}

